\title{
COMBAT VEHICLE DYNAMIC LOAD TESTS IN THE ASPECT OF THE OPERATION SAFETY
}

\section{BADANIE OBCIĄŻEŃ DYNAMICZNYCH WOZÓW BOJOWYCH W ASPEKCIE BEZPIECZEŃSTWA ICH UŻYTKOWANIA}

\author{
Waclaw Borkowski ${ }^{1}$, Piotr Rybak ${ }^{2}$, Zdzisław Hryciów $^{3}$, \\ Józef Wysocki ${ }^{4}$, Bogusław Michałowski ${ }^{5}$
}

(1-5) Military University of Technology

ul. Kaliskiego 2., 00-908 Warszawa, Poland

E-mails: (1)wborkowski@wat.edu.pl; (2)prybak@wat.edu.pl; (3) zhryciow@wat.edu.pl;

(4)jwysocki@wat.edu.pl; (5)bmichalowski@wat.edu.pl

Summary: the scientific team, working in the Mechanical Vehicle and Transport Institute of the Mechanical Department of the Military Technical Academy since the 90's, has been dealing with the analysis of dynamic loads of combat vehicles (tanks, infantry combat vehicles and wheeled armoured carriers). The work presents the combat vehicle tasks and operation tasks and conditions. Possible threats and possible effects of their influence were described on the basis of available information. The results of own model and experimental tests of dynamic loads affecting the aforementioned vehicles were presented. Selected analysis results were presented in a form of characteristics, diagrams and tables. Due to a type of analysed vehicles, the results are of qualitative nature rather than the quantitative one.

Keywords: combat vehicle, loading, investigation, safety

Streszczenie: Pracujacy, w Instytucie Pojazdów Mechanicznych i Transportu Wydziału Mechanicznego WAT, od poczatku lat 90-tych zespót naukowy zajmuje się badaniem oraz analiza obciązeń dynamicznych wozów bojowych (czolgów, bojowych wozów piechoty oraz kołowych transporterów opancerzonych). W pracy przedstawiono zadania oraz warunki eksploatacji wozów bojowych. Opisano potencjalne zagrożenia oraz, na podstawie dostepnych informacji, ewentualne skutki ich oddziatywania. Zamieszczono wyniki wtasnych badan modelowych oraz eksperymentalnych obciażen dynamicznych działajacych na w/w pojazdy. Wybrane rezultaty analiz zaprezentowano $w$ postaci charakterystyk, wykresów $i$ tabel. $Z$ uwagi na rodzaj analizowanych pojazdów rezultaty maja glównie charakter jakościowy a nie ilościowy.

Stowa kluczowe: wóz bojowy, obciązenia dynamiczne, badania, bezpieczeństwo 


\section{Introduction}

Combat vehicles (tanks, infantry combat vehicles and wheeled armoured carriers) are the basic means of combat for the land troops. They can execute combat tasks, peace and stabilization tasks in good and bad weather conditions, under the enemy artillery fire and when the mass destruction weapon is used, on the water and in the mountains, in summer and winter seasons. In general, usability of combat vehicles is defined on the basis of the following features:

- fire power,

- defence abilities,

- mobility.

Fire power - this feature defines the quantity, quality and efficiency of the main armament - guns of a particular calibre and cooperating systems.

Armour makes a shield for the combat vehicles crew and internal equipment against the enemy's weapon.

Mobility is an ability to move on any terrain. In general, it defines vehicle pickup ability and manoeuvrability as well as dynamics and ability to cross any terrain. Tank mobility is mostly determined by the factors as: combat weight, engine and drive system, suspension and caterpillar mechanism; average unit pressure, geometrical dimensions and other factors. This feature plays more and more significant role in tank's ability to survive during combat. Mobility is an important element in the so-called active defence.

Variety of combat actions, including stabilization tasks and development of anti-tank weapon force the combat vehicle manufacturers to carry out the works on new and modern solutions on a permanent basis. It refers to action efficiency improvement, motion dynamics and action safety improvements including higher probability of vehicle and crew survival.

Quality and speed of tasks performed by combat vehicles also depend on a level of dynamic loads affecting a vehicle during battlefield operations.

Presented results were obtained during own (experimental and model) tests performed according to various scientific and research works supported by the expertise, analysis of available materials and literature studies. 


\section{Dynamic loads affecting the combat vehicles}

A combat vehicle, when used in any conditions, is affected by the dynamic loads and their sources can be characterized as:

- frequent changes of engine and ground parameters during driving - gear shifting, turning, acceleration and braking,

- big dynamic loads and random overloads occurring when crossing terrain obstacles as a result of intensive body vibrations caused by terrain unevenness,

- high engine torque and high anti-torque from the ground and caterpillar chassis, when driving ahead and making fixed and free turns,

- loads when firing a gun in motion, loads caused by an impact of a missile which does not cause a puncture or a ricocheting missile,

- loads caused by anti-tank mine explosions,

- increased thermal load resulting from closed area development.

\subsection{Terrain conditions of the combat vehicle operation}

The analysis of available information as well as the authors' experience and expertise allow to assume that when combat vehicles are operated in typical conditions their body and drive system are affected by average load. This load makes about $50-75 \%$ of the maximum load. Execution of tasks that require high dynamics in the off-road conditions is always related with various unexpected obstacles. Some of them are presented on figure 1 and 2 .

Operation of systems, assemblies and mechanisms of a moving combat vehicle are significantly affected by vibrations of its armoured body (selfsupporting body) caused by driving on unpaved roads, wilderness, natural and artificial obstacles. Quantity of loads resulting from it depends on speed, dynamic features of suspension, nature of cooperation between chassis and the ground and other factors.

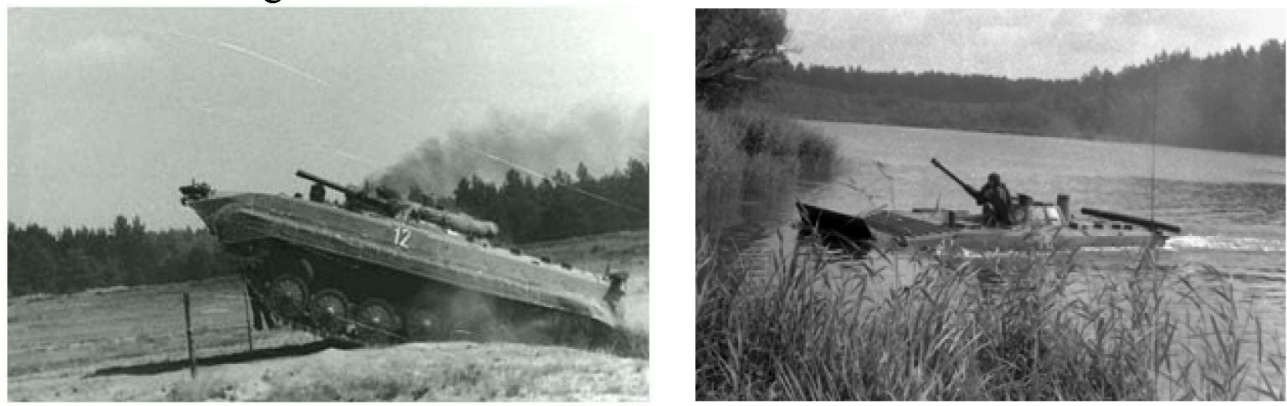

Fig.1 Caterpillar combat vehicle during crossing the terrain obstacles 

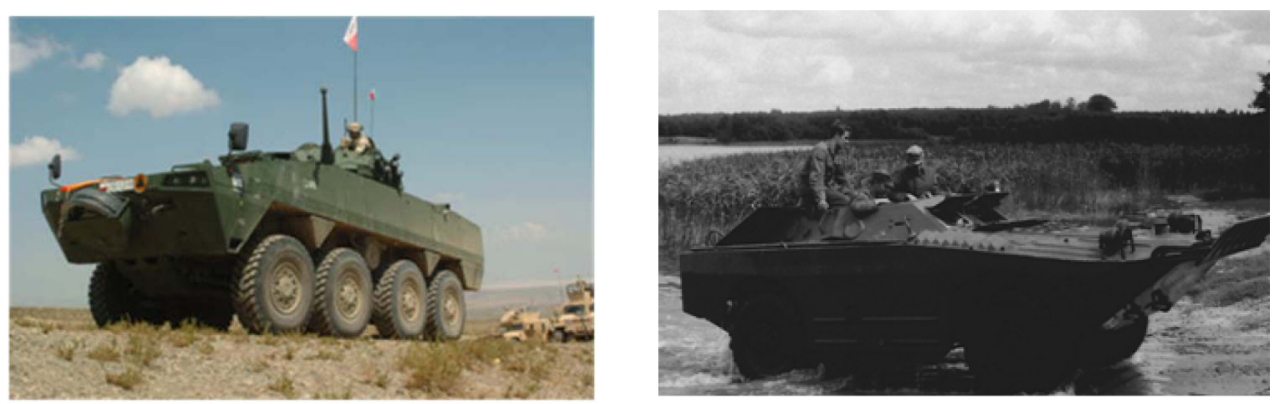

Fig. 2 Wheeled combat vehicle during off-road driving

Fig. 3 presents examples of time courses of interesting parameters registered when performing experimental tests, during observed driving of a caterpillar combat vehicle in the medium corrugated terrain.
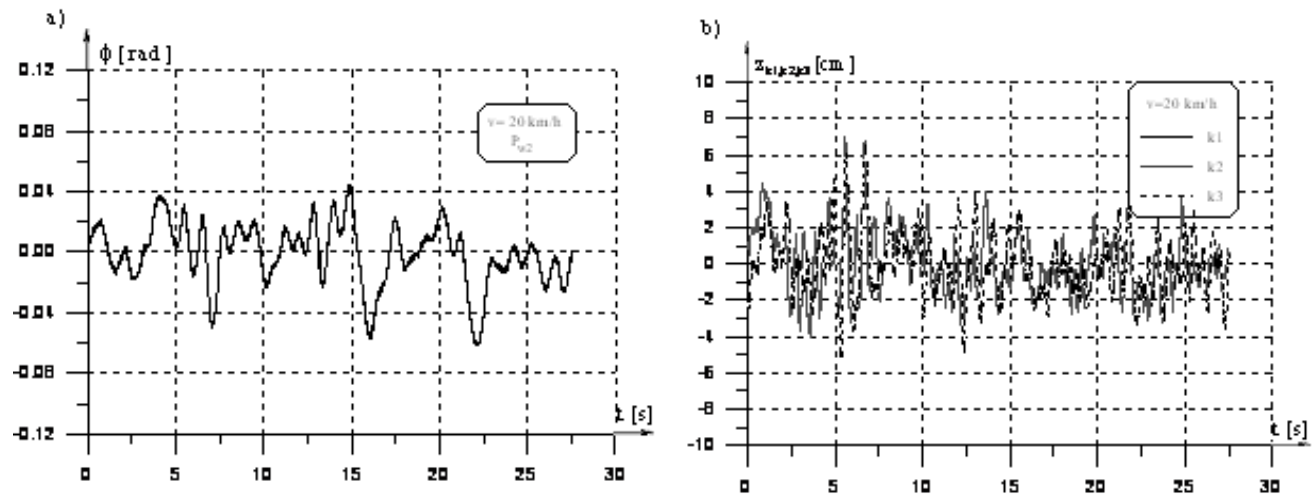

Fig. 3 Angle displacements of caterpillar combat vehicle body and vertical displacement of drive wheels during off-road driving at a set speed

Table 1 specifies maximum vertical acceleration values registered in selected locations of a caterpillar combat vehicle during a test drive on determined obstacles that correspond to typical roughness in a deformable terrain.

Table 1. Examples of vertical body accelerations registered during the test drives

\begin{tabular}{|c|c|}
\hline Driving speed $[\mathbf{k m} / \mathbf{h}]$ & Max. vertical acceleration $\left[\mathbf{m} / \mathbf{s}^{\mathbf{2}}\right]$ \\
\hline 10 & 10 \\
\hline 15 & 21 \\
\hline 20 & 28 \\
\hline
\end{tabular}


Results obtained from the tests indicate that dynamic loads affecting important tank areas, at low driving speed (below average speed in terrain) achieve high values. It can be expected that at higher speeds and with obstacles of similar parameters those loads can dangerously increase and it could affect the vehicle crew safety and internal equipment safety as well as other users' safety.

It often happens that during actions in combat conditions a vehicle comes across a single roughness, e.g. $25-35 \mathrm{~cm}$ high and of a short length. Driving at speed of app. $20-30 \mathrm{~km} / \mathrm{h}$ results in vertical accelerations of $5-8 \mathrm{~g}$ and even $12 \mathrm{~g}$ ( $\mathrm{g}=$ gravitational acceleration).

Similar situation can take place when executing police tasks within NATO or UN missions. Particularly in terrorism combat actions - destroying barricades or other barriers or convoying. Examples of these incidents, the computer simulations are presented on fig. 4 and 5. Developed model of a wheeled armoured carrier hits a technical object gate at a set speed of motion.



Fig. 4 Selected fragments from numerical simulation of incidents occurring in mission areas

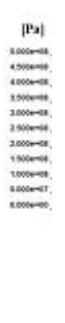

Fig. 5 Driver accelerations during collision with an obstacle at speed of 5 and $10 \mathrm{~m} / \mathrm{s}$

Depending on the gate resistance and a vehicle speed during ramming, the value of accelerations affecting the crew can amount to $6-10 \mathrm{~g}$ and more. In case of insufficient protection the crew members are highly exposed to a load. 


\subsection{Modernization and its impact on the combat vehicle load}

Combat vehicle modernization is carried out mostly in order to improve the operation efficiency. Directions of modernization include improvement of safety and battlefield survival. It can be achieved by increasing the mobility by means of engine output increase. As a consequence, it can result in increased drive system load and body load. A modernization of a basic tank can make an example. Table 1 lists the parameters of engines that can be used in a tank. The output increase in the engines $\mathrm{A}$ and $\mathrm{B}$ compared to the basic engine $\mathrm{C}$ amounts to an average level of $9 \%$ and $22 \%$, and the torque increase amounts to $10 \%$ and $30 \%$.

Table 1. Output and torque of engines to be used in a basic tank

\begin{tabular}{|c|c|c|c|}
\hline Engine model & A & B & C \\
\hline Power $[\mathrm{kW}]$ & 736 & 625 & 574 \\
\hline Torque $[\mathrm{Nm}]$ & 4300 & 3300 & 3000 \\
\hline
\end{tabular}

Fig. 6 presents the results of calculations of torques affecting individual friction mechanisms of planetary gearboxes for given maximum torques of the analyzed engines. The drive system load from the engine side is increased by the loads resulting from the cooperation of a drive wheel with a caterpillar and its impact on the supporting rollers. The level of those loads depends on:

- wear of caterpillar catches and toothed drive wheel rings,

- preliminary caterpillar belt tension.

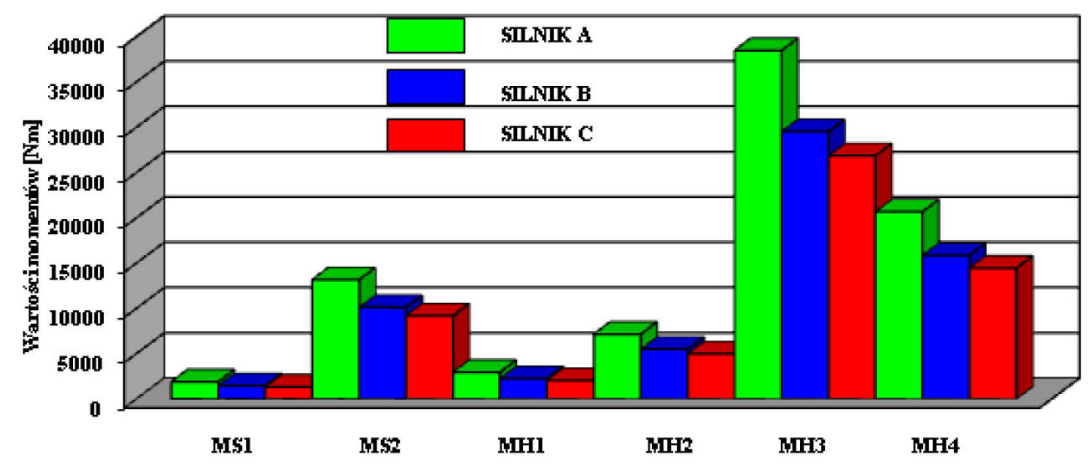

Fig. 6. Friction mechanism loads determined by an engine torque: $M S$ - torque on clutch, $\mathrm{MH}$ - torque on brake 
Use of increased output engines resulted in improved dynamic characteristic parameters of the basic tank - fig. 7, including unit drive force on caterpillars, mobility in difficult terrain and ability to cross elevations.

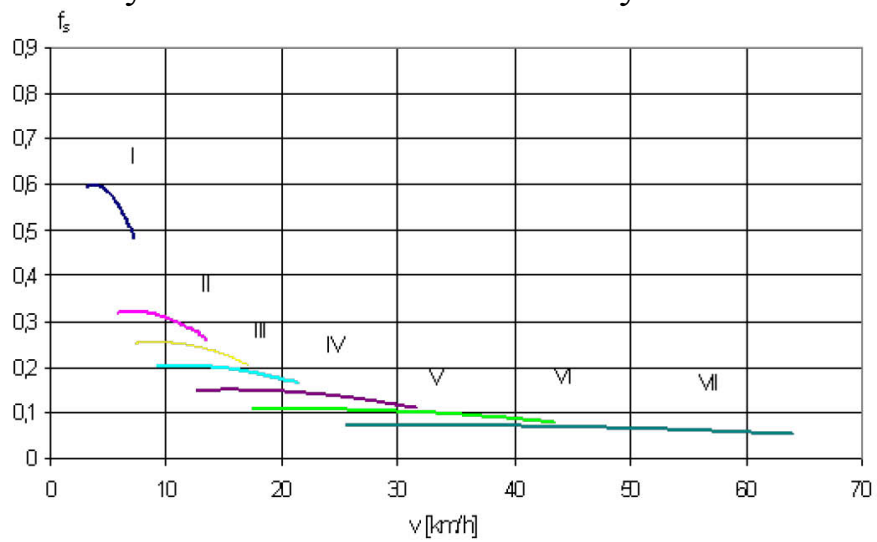

a/ Dynamic characteristic of a tank with engine $C$

Wykres 3. 1. 2. Charakterystyka dynamiczna czołgu zmodernizowanego (PT-91)

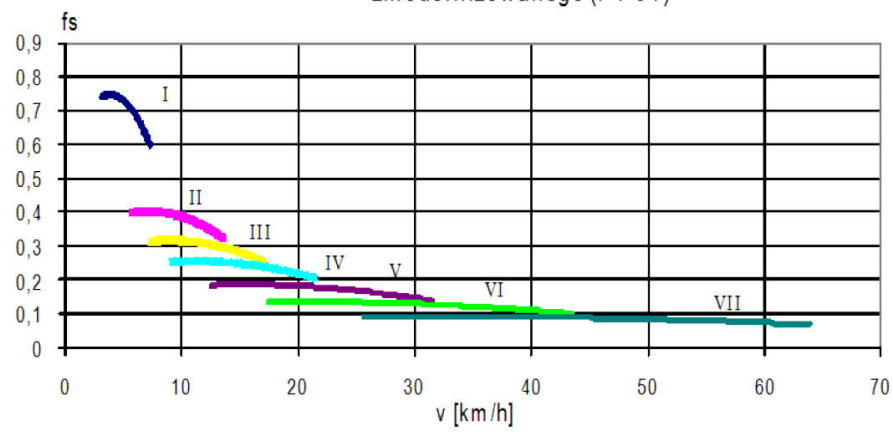

b/ Dynamic characteristic of a tank with engine A

Fig. 7 Dynamic characteristics of tanks before and after modernization, $f s-u n i t$ drive force

Improvement of traction characteristics allows to cross terrain obstacles at higher speeds. At the same time, higher dynamic loads are generated and they affect the crew members. In order to reduce exposure, the chassis and seat characteristics should be modified.

\subsection{Firing from the main armament}

Varied gun calibre and strong propellant charges cause the recoil force when firing (Fig. 8), which cannot be fully dissipated by damping elements of the counterrecoil mechanism assembly. Part of this force is taken over by a 
combat vehicle body so it means that it affects the crew, the drive system and parts of the chassis as well. Table 2 specifies rough recoil force values generated when firing the guns of various calibres. Fig. 9 presents the simulation results of the recoil force impact on a tower bottom plate of a caterpillar combat vehicle during firing. Fig. 10 presents courses of acceleration affecting the vehicle body and a driver.


Fig. 8 Combat vehicles during firing from the main armament

Table 2. Maximum recoil force value affecting the tank body load for various gun calibres

\begin{tabular}{|c|c|c|}
\hline No. & Gun calibre $[\mathrm{mm}]$ & Recoil force $[\mathrm{kN}]$ \\
\hline 1. & 25 & 25 \\
\hline 2. & 100 & 280 \\
\hline 3. & 120 & 411 \\
\hline 4. & 125 & 524 \\
\hline
\end{tabular}



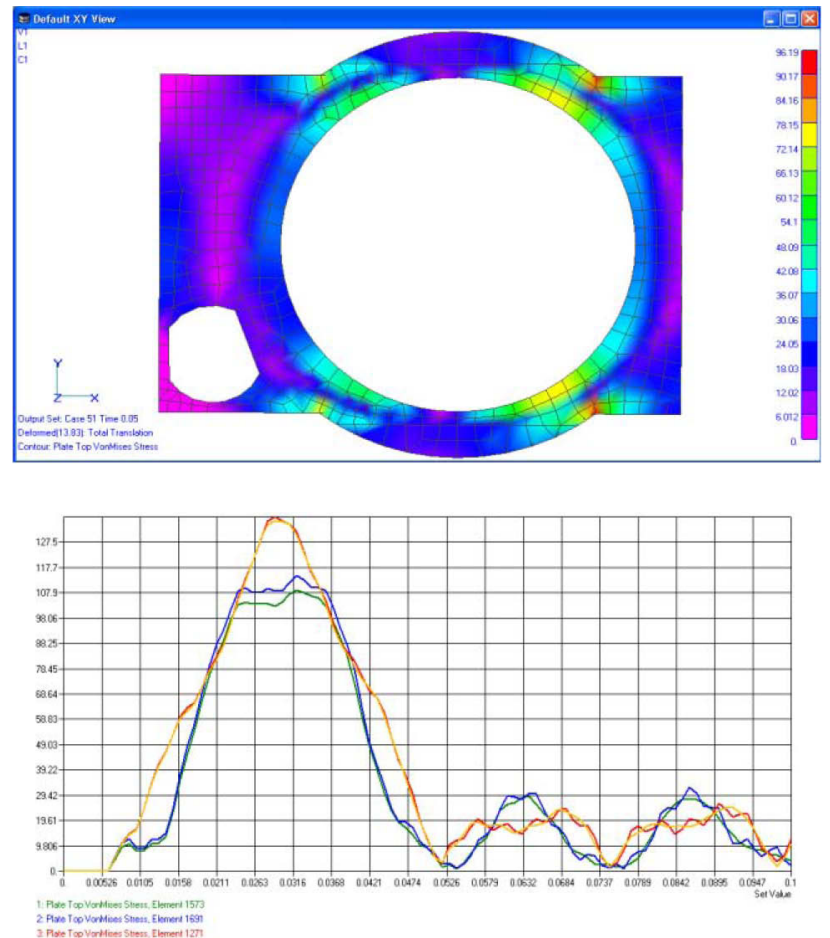

Fig. 9 Distribution of stress in a tower bottom plate at selected moment (at the top) and time course of stresses in selected model nodes (at the bottom) when firing a $120 \mathrm{~mm}$ gun.

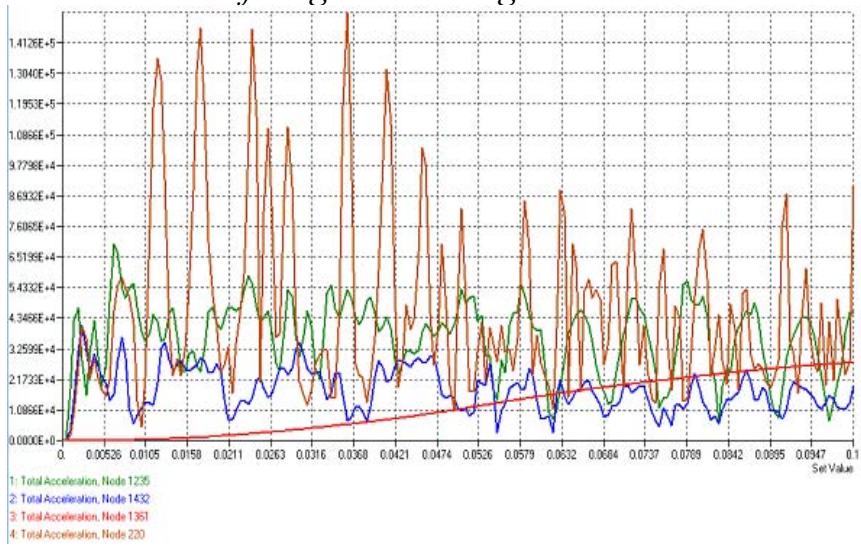

Fig. 10 Time courses of accelerations when firing from a $120 \mathrm{~mm}$ gun.

Performed simulation tests indicated that replacement of armament in combat vehicles with other types of armament needs to be preceded with a detailed analysis of support structure resistance. It is also important to estimate dynamic loads affecting the vehicle crew. According to our own 
tests, the increase of gun calibre from $100 \mathrm{~mm}$ to $120 \mathrm{~mm}$ results in a significant increase of accelerations.

The impact of a missile which does not cause a puncture or a ricochet should also be considered. Particularly in case of sabot shells or highexplosive shells. The value of armour resistance to an anti-tank missile is defined depending on assumed penetration model. Sabot shell penetration forms are shown on fig. 11.

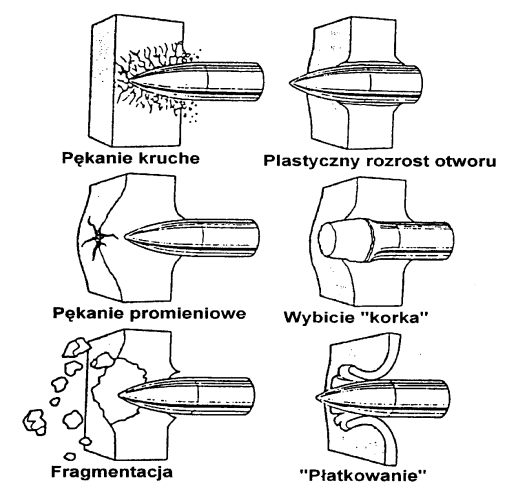

Fig. 11 Forms of armoured plate destruction by small calibre anti-tank missiles

Vehicle dynamic loads caused by a ricocheting missile can achieve maximum values (that equals the energy of a penetrating missile which does not cause a puncture) up to a value resulting from the armour sliding effect. Fig. 12 presents time courses of accelerations affecting the vehicle and the crew during a ricochet.

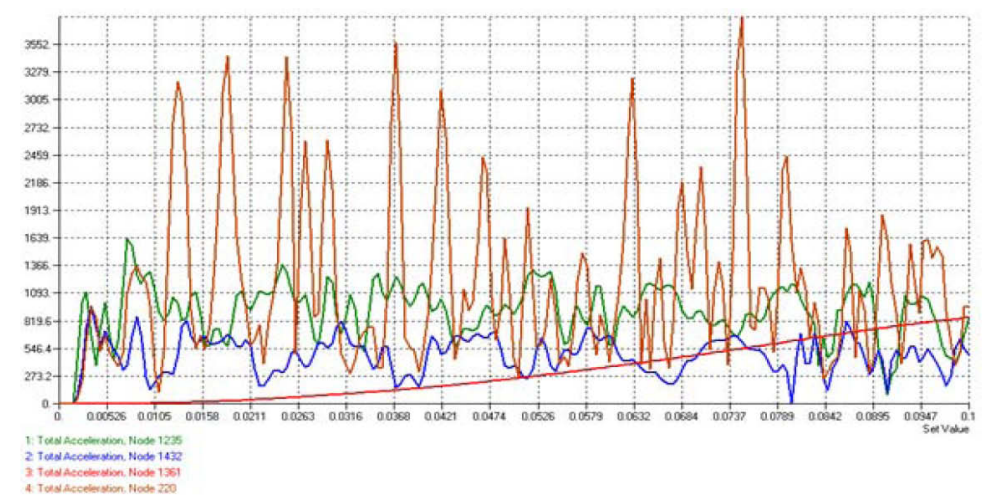

Fig. 12 Time courses of accelerations affecting the vehicle body (1432) and the vehicle mechanic-driver (1361) after a missile impact

The influence of armour type and destruction mechanisms resulting from a missile impact on the vehicle crew safety is obvious. 


\subsection{Mine explosive impact}

The influence of mines and other explosives, particularly intensity of use, can be observed in the past and current conflicts (the Balkans, Lebanon, Iraq, Afghanistan). The shock wave pressure affecting the supporting structure of a combat vehicle makes the main firepower factor of those means. Such impact significantly affects durability of a vehicle and the vehicle crew's chance to survive - fig. 13.

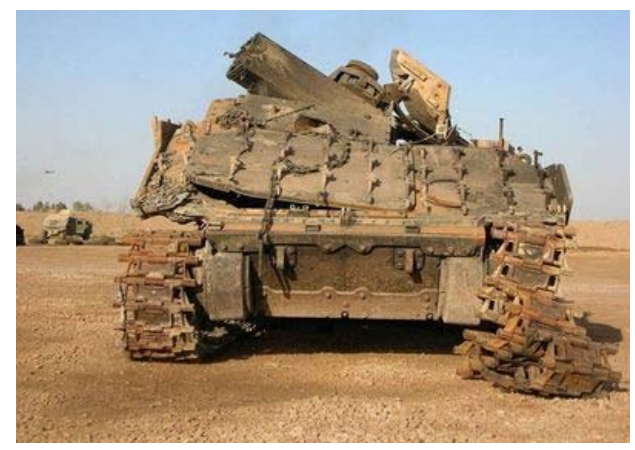

Fig. 13. The explosive impact result

Model tests, already at the design or modernization stages, allow to estimate the explosive impact on the supporting structure of a combat vehicle. Fig. 14 presents a course of deformation of the body bottom plate in the time function. Observed bottom deformations lead to permanent (plastic) distortions. Thus the technological basis of the drive system assembly and other internal devices on the body bottom are broken and as a result the combat vehicle becomes immobilized. According to the tests, the crew members are also affected by high dynamic loads that jeopardize their health and lives (depending on the explosive size). An example of antibottom mine impact on internal devices is shown on fig. 15 (own tests). Fig. 16 presents the influence of a mine detonated on the side of a wheeled armoured carrier.

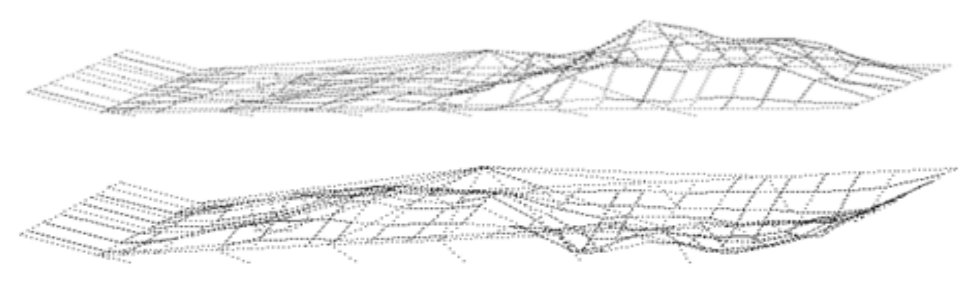

Fig. 14 Deformation of a body bottom plate of a caterpillar combat vehicle at selected moments of time 


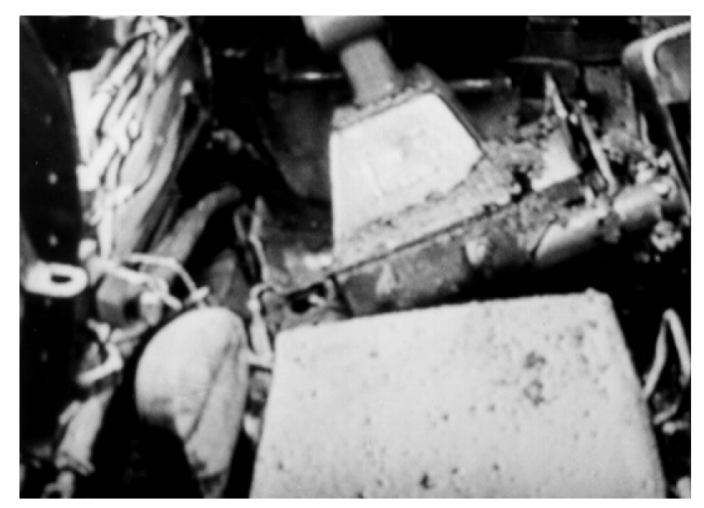

Fig. 15 Position of a caterpillar combat vehicle drive after mine explosion

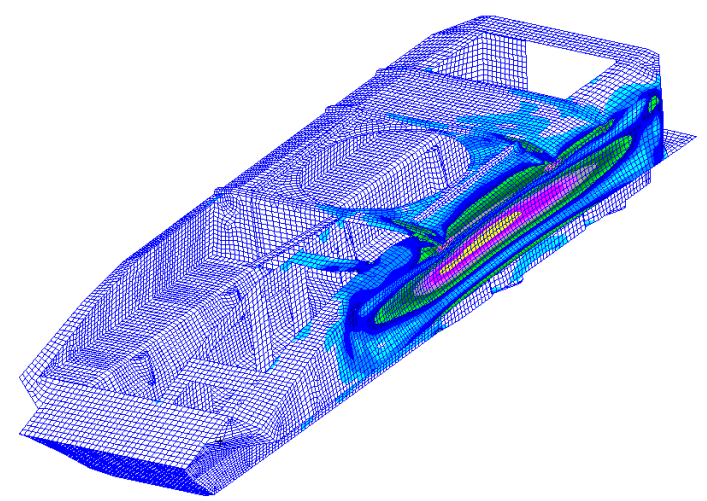

Fig. 16 Stress in a wheeled armoured carrier body after roadside mine explosion

\subsection{Thermal loads}

During combat vehicle operation in typical heavy-duty terrain conditions, characteristic drive system defects can occur:

- friction mechanism disk overheating,

- bearing and tooth overheating,

- premature oil pump wear.

Fig. 16 presents photos of some common defects of friction mechanism disks that can result from:

- high thermal load resulting from slipper operation,

- dynamically variable pressure force applied during gear shifting,

- friction disk vibration in deactivated mechanisms. 


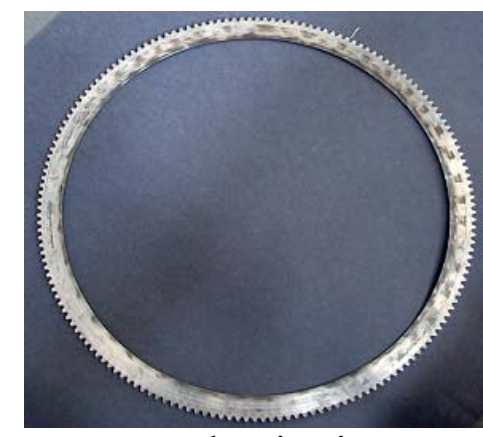

Decolourization

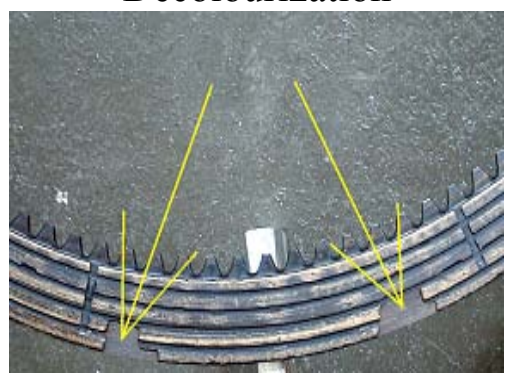

Chipping

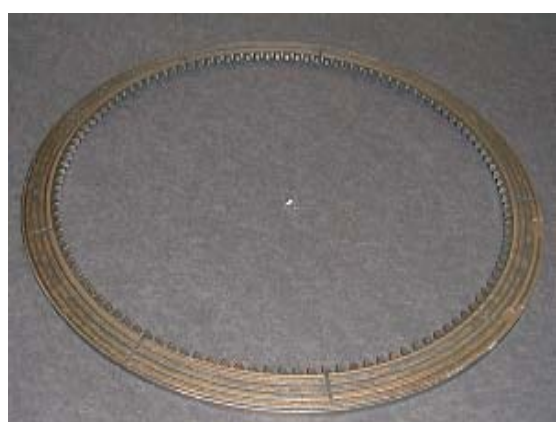

Deformation

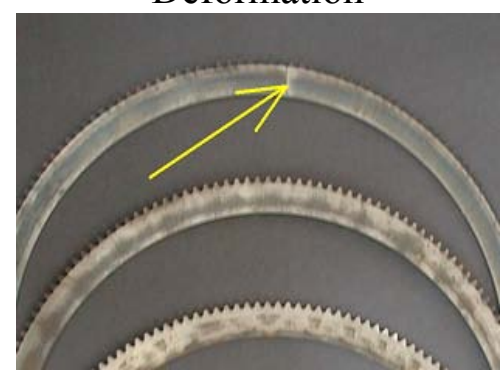

Cracking

Fig. 16 Common friction disk defects

Drive system defect can result in vehicle immobilization and then it becomes an easy target for the enemy.

\section{Final conclusions}

Combat vehicle and crew safety make one of the priorities during vehicle design and modernization. The most unfavourable accidents and expected incidents are considered in the load analysis. Unfortunately not all of them can be foreseen and it is difficult to design a perfect general-purpose vehicle. So far, the basic tanks are the most rational combat vehicle solution due to their high universality.

\section{References}

1. Borkowski W., Rybak P., Wybrane problemy ochrony gąsienicowych wozów bojowych przed obciążeniami udarowymi, III Konferencja N-T „Odporność Udarowa Konstrukcji” Rynia 23-25.10.2002.

2. PBG nr T00A 02020 ,Modelowanie i analiza sprzęgieł i hamulców wielotarczowych wozów bojowych w aspekcie dostosowania ich do silnika o zwiększonej mocy".

3. PBG Nr 0T00C00222 „Metodyka kształtowania konstrukcji bazowych W aspekcie przezbrajania na nowe rodzaje obciążeń (uzbrojenia). 
4. Borkowski W, Rybak P., Dynamic load in operation of high-speed tracked vehicles. Journal of Kones vol. 16, nr 4/2009.

5. http://militarypedia.corran.pl

The scientific work financed by the funds assigned for the science during 2007-2010 as a developing project.

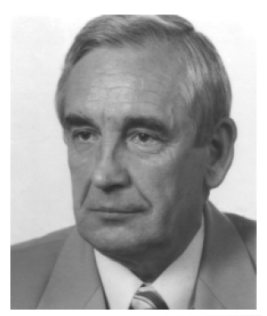

Waclaw Borkowski Prof. DSc. Eng. Professor at Military University of Technology, Faculty of Mechanics in Warsaw, Poland. Specialization: mechanical engineering, simulation and experimental testing of vehicle dynamics and road traffic safety. Membership in many scientific committees of conferences and congresses.

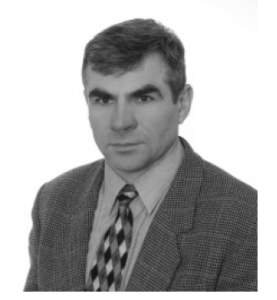

Piotr Rybak PhD. Eng. Works at Military University of Technology, Faculty of Mechanics in Warsaw, Poland. Specialization: mechanical engineering, simulation and experimental testing of combat vehicle dynamics loads in the aspect of operation safety, testing of protective structures of military vehicle.

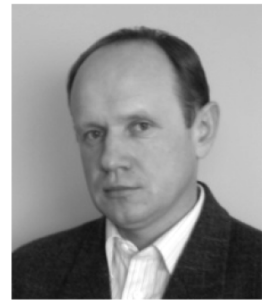

Zdzisław Hryciów PhD. Eng. Works at Military University of Technology, Faculty of Mechanics in Warsaw, Poland. Specialization: mechanical engineering, simulation and experimental testing of vehicle dynamics and suspension optimization.

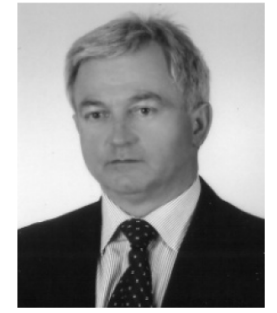

Józef Wysocki PhD. Eng. Works at Military University of Technology, Faculty of Mechanics in Warsaw, Poland. Specialization: mechanical engineering, vehicle dynamics, road traffic safety, simulation and experimental testing of vehicle suspension elements.

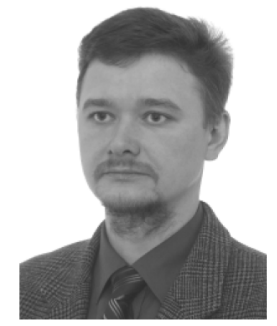

Bogusław Michałowski MSc, lecturer at Faculty of Mechanical Engineering, Military University of Technology. Specialization: modelling, simulation and experimental testing of vehicle dynamics, vibration tests of machinery, electric equipment of the vehicles. Co-author of textbook "Basics of automobile electrotechnics and electronics" and two academic scripts. 